\title{
CRISIS IN THE IDEA OF THE UNIVERSITY AND ITS CAUSES. SELECTED PROBLEMS
}

\author{
SEWERYN LESZCZYŃSKI \\ seweryn.leszczynski@gmail.com \\ University of Wrocław, Poland
}

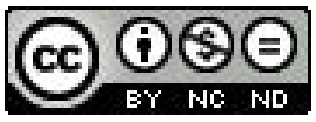

\begin{abstract}
The article is focused on the three phenomena of the crisis in the idea of the university: the fashion of postmodernism, re-evaluation of the values, link between science and the economy. The author tried to show that these processes lead to irreversible changes in thinking about the idea of university. The changes include social processes in the long period of time. In this way we can say that these phenomena can be considered as causes of this crisis. The author does not decide whether this is the fact. But it seems to be true. Anyway, we have to be careful in consideration of the crisis in the idea of the university: here nothing is certain. The article stays open to new ideas which may explain this topic.
\end{abstract}

Key words: university, crisis, postmodernism, values, science, economy

\section{INTRODUCTION}

"In all Europe universities are in crisis" (Thieme 2009, p. 33). With this viewpoint, we begin this article, which attempts to deal with the changing conditions in which today's research centers find themselves. Sounding pessimistic voices about the growing symptoms of this crisis do not have to immediately trigger anxiety, because where there is collapse and crash, there is also hope for improving the situation. It is worth starting by conceptualizing what the problem really is and what was the cause of the crisis according to which, in Jerzy K. Thieme's words prevails throughout the scientific word of the Old Continent.

The idea of the university is changing. The influence of changing perception of the times - old institutions and their role in society in the last few years has been a worldwide phenomenon. Among them we can highlight the fashion of postmodernism, re-evaluation of values or the link between science and the economy. How to organize the mechanisms of these changes and whether it could have an impact on the functioning of the university, will be the question posed by this article.

\section{THE FASHION OF POSTMODERNISM}

Is there the fashion of postmodernism? If it is considered that the crisis in the scientific world is a sign of creating in our view a general division in values or culture, we can speculate that this is a fact. Frederic Jameson describing postmodernism claims that "he is more interested in divisions than continuity" (Jameson 2011, p. IX). This is confirmed by the words of other researchers who are in favor of the theory according to which postmodernism defined new fields of researchers, which do not fall into the framework of modernism. In the words of J. Brzeziński (as quoted in 
Melosik 2009): “As write S. Best and D. Kallner »for last two decades postmodern debates raise issues that cannot be easily avoided or incorporated in already established paradigms «" (Brzeziński 1991, p. 5, quoted in: Melosik 2009, p. 82). Schism as a transition to the next stage or place is an integral component of the transformation, also the culture changes from the perspective, which we can consider science. Culture as a way to organize and manifest signs of intellectual life in the form of certain ideas and beliefs can take a linear character. At some point one idea is replaced by another which removes from pre-eminence dominant trends. Among the many intellectual trends we can talk about the rule of succession or convertibility from one fashion into another. According to Thomas Kuhn (1960's) fashion is a dominant trend, which also manifests itself in intellectual life. This convertibility can be one of the reasons for the devaluation of university values, as long as they are included in the ideological scene. About the dangers of passing into the next fashion Monika Stankiewicz-Kopeć says: "Next to short-term, transient and essentially insignificant intellectual fashion events, there are also fashions covering the whole range of continents and exciting millions of their inhabitants. Fashions dangerous, biased, capricious, changeable, sentenced on amnesia and non-existence of all areas of science and large numbers of unfashionable artists and thinkers" (Stankiewicz-Kopeć 2012). In this way disproportionate fields of science may arise and inappropriate emphasis of their themes and significance to ongoing problems. Fluency and variation are components of postmodern discourse, and about capricious fashion the best proof of the fact of previously unnoticed areas of science in the global discourse is not only the results of this variation, but also the lack of national education policy.

Postmodernism is opposed to modernism. According to Zbyszko Melosik: "Supporters of postmodernism reject the modernist idea according to which science is »a privileged form of the mind or is a mediator of truth «" (Melosik 2009, p. 82). If the goal of science is to understand which means search for truth, and if we are living in an era in which "irrationality has become fashionable again" (Popper 1997, p. 15), we are closer to the crisis than we were a few decades ago. Expanding on the impact of intellectual fashion today in the shape of scientific discourse, it is worth mentioning the mechanisms of its formation. They are not clear and explicitly expressed: "Mechanisms alone of the formation of intellectual fashion are quite vague. Whatever cannot be said at this point, one thing is certain - a fashion must have someone's name and face. Preferably the face was expressive, easily recognizable, mediumistic, as it was with Roland Barthes, Michel Foucault, Richard Rorty, Umberto Eco, Jacques Derrida" (Stankiewicz-Kopeć 2012). It is not difficult to see, that each of these persons acted as leading representatives of their trends. Whether the trend's gain in popularity was largely determined by the decisions of individual persons who took the time to demonstrate the trend as well-known and accepted. A significant role is played here by time and position of the person postulating the idea. Janusz Goćkowski analyzing scientific life and symptoms of pathology that are present here, diagnosed a tendency to "destroy normality in everyday academic life" (Goćkowski 1999, p. 34). According to his words the first proof of this is the advantage of their own ideological reasons on important issues of science: "It shows that there are more important reasons for their or their sponsors utilitarian vested 
ideological arguments than the problematic situation in science" (Goćkowski 1999, p. 34). Particularity objectives are seen nowadays as a manifestation of postmodernism. Ambiguity and lack of order and ambiguity of moral decisions are characteristic for today's world (Bauman 1996, p. 45). It may generate a series of problems, connected for example with didactic. If, as in the words of the author there has been a reverse situation to the normal, is expected that significant steps will be needed to restore the status quo ante bellum. But, will it be possible, when scientists abandon established routines and begin to engage to science, which means attempt to uncover the truth? Truth will be discussed in more detail in the next paragraph.

\section{RE-EVALUATION OF THE VALUES}

Universal moral values are the backbone of society. Without them it was impossible to educate responsible and honest people who themselves are then initiators and advocates maintaining the importance of these values. The "Koinonia of these people has formed the framework of the university for centuries. The purpose and mission the university was responsible for the preservation and transmission of cultural, moral and ethical values (...)" (Krajewska 2003, p. 72). The rejection of these paradigms has become one of the causes of the phenomenon known today as the crisis of the university, specifically, its identity crisis. The identity crisis of the university means that its structures, functions, duties and carrying out of tasks has stopped performing its functions or has been changed. The university is a community of people who are accustomed to learning and every institutional failing is a failure of the people associated with it de facto. According to words of Jerzy Semków, it can be said that "the identity crisis of the university is built into the identity crisis of modern man" (Semków 2003 p. 48). Axiological emptiness which is characterized by the absence of rules, the rejection of universal values and the crisis of authority are therefore problems that do not have the single level of interpretation. This multifaceted situation revealed in the community, is noted by Zbigniew Kwieciński asking: "Are we not, as a society, immersed in the state of anomie, I mean in the chaos of values and principles and perhaps even in axiological emptiness?" (Kwieciński 1995, p. 25). The crisis in the modern scientific world is the aftermath of this chaos, like a natural consequence of the collapse of the accuracy of composing a recent reality. So, what was the role of the university and of higher education?

The first and an important determinant defining the collapse of the high level of moral education, was the mentioned rejection of values. Dorota Pauluk claims that "its [university - S.L.] deficiencies are often identified with the idea of a departure from the traditional model of the university, from the identification of its features such as: transmission of general knowledge, the search and promotion of truth, care about integrity of knowledge, research and teaching, internal and external autonomy" (Kwieciński 1995, ibidem, p. 98). So any job that led to the transfer of general knowledge or external autonomy meant a continuity of order, a common and team affecting number of factors, both human and institutional. The university was the guarantor of unity and cohesion: "For centuries the vocation of university was the determination of the social order according to intellectual principles and established values" (Pauluk 2000, p. 97). Designation 
of this order meant that the elite university chose the direction and purpose not just of a small group of people but their actions affecting the whole community. Currently, the elite of society associated with the profession apart from teaching formulate and provide conditions for research centers which is a simple consequence of the replacement of the idea of the truth. Ideologized truth led to the freedom of manipulating its value and its typical capitalization. The existing former standard is today considerably re-evaluated. According to Jeffrey R. Brown and Remi Clignet "one of the main dogmas of academic knowledge was its search (knowledge for knowledge's sake). The importance of the university and status of scientists are not determined by »immediate usability « of their actions but by their contribution to the understanding of humanity and nature, aspiration of truth and knowledge (...)" (Melosik 2009, p. 73). To change the university, it must be a community - according to words of Elwira J. Kryńska - whose objectives can be described as "exploration and the search of truth and knowledge together with continuity of tradition of free research (...)" (Kryńska 2010, p. 75). This tradition must be preserved to allow the idealism that characterized scientists. According to Zbyszko Melosik it was result of "a neutral act for the public benefit" which was not burdened with dependency on governments and markets (Melosik 2009, p. 65). Nowadays, departure from the old privileges has led to a treatment of professors like employees of university, but not only that (Melosik 2009, p. 65). Scientific staff were slowly entering the capital market which brought great changes in knowledge management and marketing of research centers, the so-called commercialization. It is manifested in a rejection criticism which according to Joanna Winnicka-Gburek "is necessary for realizing truth, goodness and beauty" (Winnicka-Gburek 2007, p. 159).

Another important reason for the displacement of interest in science in other direction than for the search for truth was the influence of an ideology which came with the end of Second World War. Instead of focusing on their mission, centres took an interest in social problems: "Since the end of Second World War - G. Himmelfarb argues - tasks of universities became solving problems connected with environmental pollution, poverty, crime, discriminations of minorities, etc." (Pauluk 2000, p. 100). In this way the great problems of humanity have been borrowed and drawn into the orbit of interest of people whose vocation was quite different. Dorota Pauluk concludes and says that: "The natural way of things was the fact that the focus has moved from the so-called liberal education to socially useful learning embedded in popular ideologies. The consequence of this is politicization of the universities, where race, class and sex »are the holy trinity « that governs education in America" (Pauluk 2000, p. 100). We come back to the initial explanations in which I talked about the impact of intellectual fashion. Nebulous mechanisms that govern its formation can thus explain the above mentioned displacement. It implies that "significant numbers of eminent professors declared their support for specific social groups or ideologies while rejecting the axiological and anthropological dimension" (Pauluk 2000, p.100). The change in paradigms has become dangerous not only for people associated closely with science. Interacting with other social groups, research centers themselves have destroyed an image, which until recently was believed by young students for the first time beyond the walls of universities. Their faith in the power of the truth became lopsided and its rebuilding is not a simple task today. 
While a few decades ago, the crisis of the university did not impact on the whole society, today the impact of globalization has led to the need for authorities to respond to the needs of scientific centers of the world economy. Hence this growing dependence of science has led to a link with the capital market.

\section{LINK BETWEEN SCIENCE AND THE ECONOMY}

To illustrate some causes of the link between science and the educational system, we can present the opinion of Heinz Sünker, a professor of social pedagogy and social policy:

"For example from the experiences of U.S. and U.K. it is clear that to the fashionable preference for institutional autonomy and parental choice and celebration of diversity of educational services, position of the majority of the citizens in class society, which is characterized by unequal access to cultural and material resources, does not change (Cf. Whitty, 1997, 1998; Henig, 1994). In fact market strategies lead to the intensification of differences. Victims because of their weak market position, are marginalized and are not able to change anything. The growing trend towards more and more rights based on the consumer and not the citizen lead not only to transition from the public education to private schools but also to competition for customers in the market. This situation seems to be a response to criticisms about bureaucratic social security benefits by the state, but in fact it is the removal of major decisions in the field of education from the public sphere into the private sphere, with significant consequences for social justice (Whitty, 1998, p. 100)" (Sünker, 2010, p. 199 - 200).

Concentration into the hands of the citizen of the decisive voice in choosing their path of education has been caused by the more and more visible trend of prioritizing the rank-and-file initiatives. As long as politicians allowed free of charge studies, it was impossible to distinguish the individual voices that went on to influence the shape of its path. Because "whether education was a private or public good was decided by politicians, there was no objective evidence" (Thieme 2009, p. 71). Permission from authorities has led to the creation of the new rules. An elite private sphere began to control the rights, privileges and finally other ways of reaching customers outside the public sphere. Thus, customer demands began to change and evolve in order to increase the efficiency and utility of teaching. This education was only available to the elite which has not been based on its own knowledge base but the resources held. Therefore the rules of the market began to gradually impact on higher education, which began to stratify. Processes were particularly evident in the Poland of the 90's. One trend has become the multiplication of private universities which effectively compete with public universities which began to shape the educational policy of the country. The results of the competition was to increase competiveness and productivity of schools, which in the case of the public sphere occurred at the expense of investment in research. This social phenomenon has led to mass higher education which has resulted in incalculable consequences for the Polish education and society. According to Beata Gola, the "mass character of education becomes a feature of the university and also stops it from being an elite institution as in the past. Currently, it does not educate the intellectual elite of society, but the center ground. Massive processes and marketization of higher education have impacted on the quality of higher education resulting in a reduction of its level" (Gola 2007, p. 176). The 
above - mentioned mass character of education "is closely linked with the needs of the labor market and the development of a market economy" (Gola 2007, p. 174). Therefore the impossibility to be completely cut off from the sphere of the economy has brought new solutions that combine science with business. According to some people they seem to be necessary. Opposing institutional business intelligence (BI) analysts, indicate the need for the use of this latter approach in different areas of the university. One of the objectives of BI in an environment of higher education is to create initiatives that will lead to direct its activities towards the corporate business environment, which could then confirm their participation in the education sector (Alcolea, Rivera 2010, p. 414). Cooperation between two areas has been in numerous instances in the form of publiclyfunded projects, which have provided support for international partners. These actions are: LINK (Canada), ERATO (Great Britain), TDDP (Japan), ESPRIT (European Union), (Maier 2010, p. 172 - 173). Mutuality for both sectors seems now to be a truism.

In the face of change and evolving in the direction of post-national society, such as society of United States and Great Britain and in the face of changes and information revolution in the world, the university cannot function according to the modernism. Nowadays, people involved in learning and students are more and more often faced with the increasing importance of cross-border education which is characterized by:

- "chance of distance learning thanks to innovations in information and communication technologies, creating new types of institutional education such as profitable, private schools,

- pursuance of all of types of institutional education outside the home country, the existence of different legal forms of institution such as branches, franchises, twinning arrangements, cross- border programs, etc." (Thieme 2009, ibidem, p. 78).

In the face of new communication structures, internationality and fluidity of knowledge, science has gone beyond the traditional schemes. In this way we come to the phenomenon of multiculturalism, to the effect of duplication and infiltration of different social strata and structures of society which bring positive and negative change. But this is a topic for separate consideration.

\section{CONCLUSION}

The three discussed components do not include all the issues. Undoubtedly, they have an impact on education and contemporary reality of education and they infiltrate each other. The fashions for postmodernism and re-evaluation of values are intellectual constructs whose causes can be a departure from the role of universities as advocates of truth and a translocation of its tasks into the sphere of economy. Links with the economy are also results of the ideologisation and politicisation of science which took place in the first decades after the Second World War. Another reason for reorganization of educational policy and its connection with business was putting education into the private sector. Correlation of these phenomena and their mutual penetration allows us to construct various discourses explaining the changes that are happening before our eyes. It seems that the truth about the contemporary crisis is 
multilayered and ambivalent, particularly, that the correct diagnosis does not always lead to the appropriate conclusion. What is certain is that for the university - according to Leszek Kołakowski - "there is no other source of life than stubborn insistence on universal rules of good use of the intellect" (Kołakowski 2009, p. 266-277). In this way we return to the principles that guided universities through the centuries.

\section{BIBLIOGRAPHY}

Alcolea J.J., Rivera M. (2010), Institutional Intelligence: Does Business Intelligence Apply to Higher Education?, [in:] Rudak L. (ed.), University Information Systems. Selected Problems, Difin, Warszawa.

Bauman Z. (1996), Etyka ponowoczesna, trans. J. Bauman, J. Tokarska-Bakir, PWN, Warszawa.

Brzeziński J. (1991), Nauki humanistyczne i spoteczne - między uniwersytetem a praktyka, "Zagadnienia Kulturoznawstwa" 1.

Goćkowski J. (1999), Uniwersytet i tradycja w nauce, Secesja, Kraków.

Gola B. (2007), Tradycja uniwersytecka wobec masowości wyższego wykształcenia i nacisków rynku pracy, [in:] Kostkiewicz J. (ed.), Uniwersytet i wartości, Impuls, Kraków 2007.

Jameson F. (2011), Postmodernizm, czyli logika kulturowa późnego kapitalizmu, trans. M. Płaza, WUJ, Kraków.

Kołakowski L. (2009), Czy Pan Bóg jest szczęśliwy i inne pytania, Znak, Kraków.

Kostkiewicz J. (ed.) (2007), Uniwersytet i wartości, Impuls, Kraków 2007.

Krajewska A. (2003), Wyzwania wobec uniwersytetu XXI wieku, [in:] Ładyżyński A, Raińczuk J. (eds.), Uniwersytet - między tradycją a wyzwaniami wspótczesności, Impuls, Kraków.

Kryńska Elwira J. (2010), Uniwersytet - podmiot, czy obiekt zmian?, [in:] Piekarski J., Urbaniak-Zając D. (eds.), Innowacje w edukacji akademickiej. Szkolnictwo wyższe w procesie zmiany,. Wyd. Uniwersytetu Łódzkiego, Łódź.

Kwieciński Z. (1995), Socjopatologia edukacji, Mazurska Wszechnica Nauczycielska w Olecku, Olecko.

Ładyżyński A, Raińczuk J. (eds.) (2003), Uniwersytet - między tradycją a wyzwaniami wspótczesności, Impuls, Kraków.

Maier K. (2010), Potencjał wspótpracy sektora przemystowego i uczelni wyższych, trans. M. Kulesza, [in:] Piekarski J., Urbaniak-Zając D. (eds.), Innowacje w edukacji akademickiej. Szkolnictwo wyższe w procesie zmiany, Wyd. Uniwersytetu Łódzkiego, Łódź.

Melosik Z. (2009), Uniwersytet i społeczeństwo. Dyskurs wolności, wiedzy i władzy, Impuls, Kraków.

Pauluk D. (2000), Uniwersytet w blasku ideałów i w cieniu codziennego życia. Kontekst historyczny i wspótczesny, [in:] Pauluk D. (ed.), Student na wspótczesnym uniwersytecie - ideaty i codzienność," Impuls, Kraków.

Pauluk D. (ed.) (2000), Student na wspótczesnym uniwersytecie - ideaty i codzienność, Impuls, Kraków.

Piekarski J., Urbaniak-Zając D. (eds.) (2010), Innowacje w edukacji akademickiej. Szkolnictwo wyższe w procesie zmiany,. Wyd. Uniwersytetu Łódzkiego, Łódź.

Popper K.R. (1997), W poszukiwaniu lepszego świata, trans. A. Malinowski, Książka i Wiedza, Warszawa.

Rudak L. (ed.) (2010), University Information Systems. Selected Problems, Difin, Warszawa.

Semków J. (2003), Tożsamość uniwersytetu wobec kryzysu wartości świata ponowoczesnego, [in:] Ładyżyński A., Raińczuk J. (eds.), Uniwersytet - między tradycja a wyzwaniami wspótczesności, Impuls, Kraków.

Sünker H. (2010), Nowe spojrzenie na ideę uniwersytetu. Edukacja (Bildung), polityka a spoteczeństwo, trans. W. Pskit, [in:] Piekarski J., Urbaniak-Zając D. (eds.), Innowacje w edukacji akademickiej. Szkolnictwo wyższe w procesie zmiany, Wyd. Uniwersytetu Łódzkiego, Łódź.

Thieme J.K. (2009), Szkolnictwo wyższe. Wyzwania XX wieku. Polska, Europa, USA., Difin, Warszawa.

Winnicka-Gburek J. (2007), Krytycyzm wobec prawdy i piękna jako nieprzemijających wartości edukacji uniwersyteckiej, [in:] Kostkiewicz J. (ed.), Uniwersytet i wartości, Impuls, Kraków.

\section{NETOGRAPHY}

Stankiewicz-Kopeć M. (2012), »Jałowe podniecenie«, czyli o modach intelektualnych, http://www.deon. $\mathrm{pl} /$ czytelnia/czasopisma/ perspektywy-kultury/art,1,jalowe-podniecenie-czyli-o-modachintelektualnych.html\#_ftnref43, retrieved: 20.07.2012. 